\title{
Effects of different feeder layers on culture of bovine embryonic stem cell-like cells in vitro
}

\author{
Shan Cong • Guifang Cao $\cdot$ Dongjun Liu
}

Received: 15 July 2013/Accepted: 30 September 2013/Published online: 8 May 2014

(C) The Author(s) 2014. This article is published with open access at Springerlink.com

\begin{abstract}
To find a suitable feeder layer is important for successful culture conditions of bovine embryonic stem cell-like cells. In this study, expression of pluripotency-related genes OCT4, SOX2 and NANOG in bovine embryonic stem cell-like cells on mouse embryonic fibroblast feeder layers at 1-5 passages were monitored in order to identify the possible reason that bovine embryonic stem cell-like cells could not continue growth and passage. Here, we developed two novel feeder layers, mixed embryonic fibroblast feeder layers of mouse and bovine embryonic fibroblast at different ratios and sources including mouse fibroblast cell lines. The bovine embryonic stem cell-like cells generated in our study displayed typical stem cell morphology and expressed specific markers such as OCT4, stage-specific embryonic antigen 1 and 4, alkaline phosphatase, SOX2, and NANOG mRNA levels. When feeder layers and cell growth factors were removed, the bovine embryonic stem cell-like cells formed embryoid bodies in a suspension culture.
\end{abstract}

\section{S. Cong · G. Cao}

Department of Veterinary, Inner Mongolia Agricultural University, Hohhot 010018, MO, People's Republic of China

D. Liu ( ()

Key Laboratory of Mammalian Reproductive Biology and Biotechnology, Ministry of Education, Inner Mongolia University, Hohhot 010021, MO, People's Republic of China

e-mail: liujingyu1600@sina.cn
Furthermore, we compared the expression of the pluripotent markers during bovine embryonic stem cell-like cell in culture on mixed embryonic fibroblast feeder layers, including mouse fibroblast cell lines feeder layers and mouse embryonic fibroblast feeder layers by real-time quantitative polymerase chain reaction. Results suggested that mixed embryonic fibroblast and sources including mouse fibroblast cell lines feeder layers were more suitable for long-term culture and growth of bovine embryonic stem cell-like cells than mouse embryonic fibroblast feeder layers. The findings may provide useful experimental data for the establishment of an appropriate culture system for bovine embryonic stem cell lines.

Keywords Bovine embryonic stem cell-like cells · Feeder layer · Pluripotency-related gene · Real-time quantitative PCR

\section{Introduction}

Embryonic stem cells have been derived from the inner cell masses (ICM) of blastocysts in many species. They are capable of unlimited undifferentiated proliferation on feeder layers and remain karyotypically normal and phenotypically stable. In addition, embryonic stem cells have the ability to differentiate into a wide variety of cell types in vivo 
and in vitro (Christoforou et al. 2010; Zeevi-Levin et al. 2010; Evans and Kaufman 1981). Embryonic stem cell lines have been established from pigs, humans, sheep, mice and rabbits (Piedrahita et al. 1990; Thomson et al. 1998; Wells et al. 1997; Evans and Kaufman 1981; Graves and Moreadith 1993). To date, suitable culture conditions for preventing spontaneous differentiation of bovine embryonic stem cells have not been established despite the extensive efforts devoted to the generation of stable bovine embryonic stem cell or bovine embryonic stem cell-like cell lines (Cibelli et al. 1998; Iwasaki et al. 2000; Mitalipova et al. 2001; Saito et al. 2003; Stice et al. 1996; Wang et al. 2005; Strelchenko 1996; Gong et al. 2010). Because of their potential use for targeted gene manipulation, isolation of bovine embryonic stem cells in livestock species could have numerous agricultural, biomedical and pharmaceutical applications (Anand et al. 2011). Thus, improvements are needed in order to maintain the undifferentiated pluripotent state of bovine embryonic stem cell or bovine embryonic stem cell-like cell lines.

Previous studies attempted to use different kinds of feeder cells to support embryonic stem cell growth and prevent cell differentiation (Piedrahita et al. 1990; Smith and Hooper 1987). Researchers often traditionally use single mouse embryonic fibroblast or bovine embryonic fibroblast as feeder layers to support bovine embryonic stem cell growth (Seizo et al. 1998; Muñoz et al. 2008). Several studies suggest that heterologous murine embryonic fibroblast feeder layers are better than homologous feeder layers for most embryonic stem cells (Lim and Bodnar 2002). However, murine embryonic fibroblast feeder layers tend to lose capacity to support proliferation of bovine embryonic stem cell-like cells with increasing passages, and the reason for this remains unclear. Therefore, it is necessary to find a more suitable feeder layer system for bovine embryonic stem cell-like cell growth. The mixed embryonic fibroblast feeder layers were produced from mouse and bovine embryonic fibroblast at different ratios. The sources including mouse fibroblast cell line (STO) were derived from mouse embryonic fibroblasts, were resistant to 6-thioguanine and ouabain, and were sensitive to hypoxanthine guanine phosphoribosyl transferase (HPRT) and hypoxanthine, aminopterin, and thymidine (HAT), as well as negative for mouse poxvirus (Park et al. 2003). Yet, few researchers have compared the effects of using different types of feeder layers for the culture of bovine embryonic stem cell-like cells.

Recent findings having identified the transcription factors involved in the regulation of pluripotency and self-renewal in embryonic stem cells may provide keys that enable the derivation of embryonic stem cells in livestock species. It is believed that the transcription factors OCT4, SOX2, and NANOG play significant roles in maintaining pluripotency and self-renewal of embryonic stem cells (Sun et al. 2006; Huang et al. 2010). The correct expression level of OCT4, SOX2, and NANOG is considered a key marker for embryonic stem cells because it is essential for maintenance of an undifferentiated state, when the expression of OCT4, SOX2, and NANOG have decreased or disappeared, the stem cells have usually differentiated (Avilion et al. 2003; Pesce and Schöler 2001; Miyanari and Torres-Padilla 2012). However, the expression of the maker genes in the bovine embryonic stem cells needs more research.

In this study, we compared the culture effects of feeder layers composed of different cell types on bovine embryonic stem cell-like cells. Our findings may provide useful data for the establishment of authentic bovine embryonic stem cells lines.

\section{Materials and methods}

\section{Preparation of feeder cell layers}

Irradiated primary murine embryonic fibroblast cells (Key Laboratory of Mammalian Reproductive Biology and Biotechnology Ministry of Education, Huhhot, China) were used as described previously (Reubinoff et al. 2000). For the preparation of bovine embryonic fibroblast, bovine fetuses at 4-6 weeks were washed with warm saline. After removal of the head, limbs and innards, the carcasses were cut into pieces. The tissue pellets were placed on $100 \mathrm{~mm}$ dishes (Corning Life Sciences, Corning, NY, USA) and incubated for $30 \mathrm{~min}$ at $37^{\circ} \mathrm{C}$ under an atmosphere of $5 \% \mathrm{CO}_{2}$. Bovine embryonic fibroblast growth medium (Cell Applications, San Diego, CA, USA) was added for further culture. The medium was changed every 2 days and passaged every 4-6 days. The bovine embryonic fibroblast at the fifth or sixth passage were inactivated in a medium DMEM/F12 (Gibco, Grand Island, NY, USA) containing $10 \mathrm{ng} / \mathrm{ml}$ 
mitomycin-C (Sigma, St. Louis, MO, USA) for 2.5-3 h, washed three times with $\mathrm{Ca}^{2+}$ and $\mathrm{Mg}^{2+}$ free phosphate buffered saline [PBS(-)] and then treated with $0.25 \%$ trypsin- $0.02 \%$ EDTA solution. The trypsinized cells were harvested by centrifugation at $500 \mathrm{~g}$. For preparation of mixed feeder layers with murine embryonic fibroblast and bovine embryonic fibroblast feeder layers, the two fibroblasts were, respectively, counted and mixed together according to the ratios of $0: 1,1: 1,1: 2,2: 1$ and 1:0. The mixture was then inoculated based on a density of $2-2.5 \times 10^{4}$ cells $/ \mathrm{cm}^{2}$, wells in a four-well plate coated with $0.1 \%$ gelatin (Sigma). Both murine embryonic fibroblast and bovine embryonic fibroblast were plated 1 day before inner cell masses were seeded (Muñoz et al. 2008; Roach et al. 2006; Bettiol et al. 2007; Vitezslav et al. 2006; Li et al. 2004). The bovine embryonic stem cell-like cells were cultured on mixed feeder layers using bovine embryonic stem celllike basic culture medium which consisted of $90 \%$ DMEM/F12 (Gibco) supplemented with $10 \%$ fetal bovine serum (Gibco), $0.1 \mathrm{mM} \beta$-mercaptoethanol (Chemicon, Temecula, CA, USA), $0.1 \mathrm{mM}$ nonessential aminoacids (Chemicon), $100 \mathrm{IU} / \mathrm{ml}$ penicillin (Gibco), $0.05 \mathrm{mg} / \mathrm{ml}$ streptomycin (Gibco), $20 \mathrm{ng} / \mathrm{ml}$ leukemia inhibitory factor (LIF) (Millipore, Billerica, MA, USA) and $10 \mathrm{ng} / \mathrm{ml}$ basic fibroblast growth factor (bFGF) (Promega, Madison, WI, USA). The STO cell line was purchased from the Chinese Academy of Sciences and cultured in Dulbecco modified Eagle medium (DMEM) high-glucose (Gibco) supplemented with $10 \%$ fetal bovine serum (Gibco). Cells were treated with $10 \mathrm{mg} / \mathrm{ml}$ mitomycin C (Sigma) for $1.5 \mathrm{~h}$.

The mitomycin C treated STO cells were extensively washed in PBS and replated at 2-2.5 $\times 10^{4}$ cells $/ \mathrm{cm}^{2}$ in a four-well plate coated with $0.1 \%$ gelatin (Sigma). STO cells were plated 1 day before inner cell masses were seeded. Basic culture medium of bovine embryonic stem cell-like cells was as described above.

In vitro fertilization (IVF) derived embryos

Oocytes collected from cattle ovaries at an abattoir were cultured in TCM 199 medium (Gibco, Gaithersburg, MD, USA) supplemented with $10 \mathrm{mmol} / \mathrm{l}$ Hepes (Sigma), $1 \mu \mathrm{g} / \mathrm{ml}$ estradiol (Sigma) and $10 \mu \mathrm{g} / \mathrm{ml}$ follicle stimulating hormone (Kawazaki, Tokyo, Japan) for 22-24 h. The mature oocytes were fertilized in vitro using commercial bovine semen (Inner Mongolia Livestock Breeding and Improving Center, 87 Huhhot, China) as described previously (Tervit et al. 1972). The zygotes were cultured in an in vitro production system using SOFaa medium (Key Laboratory of Mammalian Reproductive Biology and Biotechnology Ministry of Education, Huhhot, China) supplemented with $10 \%$ fetal bovine serum (Gibco). The blastocysts were hatched in 8-11 days. The hatched blastocysts were cultured on feeder layers with culture medium which consisted of $90 \%$ DMEM/F12 (Gibco) supplemented with $10 \%$ fetal bovine serum (Gibco), $0.1 \mathrm{mM} \beta$-mercaptoethanol (Chemicon), $0.1 \mathrm{mM}$ nonessential amino acids, $100 \mathrm{IU} / \mathrm{ml}$ penicillin, $0.05 \mathrm{mg} / \mathrm{ml}$ streptomycin, $20 \mathrm{ng} / \mathrm{ml} \mathrm{LIF,} 10 \mathrm{ng} / \mathrm{ml} \mathrm{bFGF}$. After the hatched blastocysts attached on the feeder layers, inner cell masses that grew well were used for passaging.

Mechanical passaging method of bovine embryonic stem cell-like cells

Embryonic stem cell-like colonies grew well after the ICMs had been cultured on feeder layers for 3-5 days. For the mechanical passaging, the colonies were dissected in a microdrop under a microscope by repeated pipetting using a micropipette. The disaggregated colony cells were reseeded onto new feeder layers. The cells were cultured in basic culture medium of bovine embryonic stem cell-like cell.

Alkaline phosphatase staining

Alkaline phosphatase (ALP) activity was determined as previously described (Takahashi and Yamanaka 2006). Briefly, culture medium was removed from the plates and bovine embryonic stem cell-like cells were fixed with $4 \%$ paraformaldehyde for $20 \mathrm{~min}$. Fixed cells were washed twice with PBS and stained in $200 \mu \mathrm{g} / \mathrm{ml}$ naphtol AS-MX phosphate (Sigma) and $1 \mathrm{mg} / \mathrm{ml}$ Fast Red TR salt (Sigma) in $100 \mathrm{mM}$ Tris buffer, $\mathrm{pH} 8.2$ for $30 \mathrm{~min}$ at room temperature. Staining was terminated by washing cultures in PBS. Positive ALP staining was characterized by red color.

Immunocytochemical staining

Before preparation of feeder layers, the sterile coverslip was placed in the well in a four-well plate. Bovine 
embryonic stem cell-like cells grown on coverslips were washed, fixed with $4 \%$ paraformaldehyde, permeabilized with PBS containing $0.1 \%$ (vol/vol) Triton X-100, and incubated sequentially with $0.4 \%$ bovine serum albumin (Sigma) in PBS. The cells were pretreated with $10 \%$ normal goat serum (Hyclone, Logan, UT, USA)-PBS for $30 \mathrm{~min}$. They were then incubated with monoclonal antibodies against OCT4, stage-specific embryonic antigen 1 and 4 (SSEA-1 and SSEA-4), followed by secondary antibodies (Biosynthesis Biotechnolgy Co. Ltd., Beijing, China, bsf0368G), using an embryonic stem cell marker sample kit (Chemicon, Temecula, CA, USA) according to the protocol supplied by the manufacturer. Immunofluorescence images were observed under a fluorescence microscope.

In vitro differentiation

To induce embryoid body (EB) formation, bovine embryonic stem cell-like colonies were cut into small pieces, then cultured in 35-mm feeder layer-free petri dish, cultured with LIF and bFGF-free embryonic stem cell suspension (medium: $90 \%$ DMEM/F12 (Gibco) supplemented with $10 \%$ fetal bovine serum (Gibco), $0.1 \mathrm{mM} \beta$-mercaptoethanol (Chemicon), $0.1 \mathrm{mM}$ nonessential amino acids, $100 \mathrm{IU} / \mathrm{ml}$ penicillin, $0.05 \mathrm{mg} / \mathrm{ml}$ streptomycin) for 7-10 days, and observed under microscope.

\section{OCT4, SOX2 and NANOG expression}

Expression of pluripotent factors was also detected by reverse transcriptase-polymerase chain reaction (RTPCR). Total RNA was prepared using a QIAGEN RNeasy kit (QIAGEN, Valencia, CA, USA). Standard reverse-transcription reactions were performed with $500 \mathrm{ng}$ of total RNA using random hexamers and AMV reverse transcriptase (Roche Molecular Biochemicals, Mannheim, Germany). The PCR was carried out with $2 \mathrm{ml}$ of cDNA template, $1 \mathrm{ml}$ of $10 \mathrm{mM}$ dNTP mixtures, 10 pmol of OCT4, SOX2 and NANOG. The OCT4, SOX2 and NANOG RNA transcripts were amplified using 5 min for denaturation at $94{ }^{\circ} \mathrm{C}$, followed by 40 cycles at $94{ }^{\circ} \mathrm{C}$ for $30 \mathrm{~s}$, with the final extension at $72{ }^{\circ} \mathrm{C}$ for $10 \mathrm{~min}, 62{ }^{\circ} \mathrm{C}$ for $30 \mathrm{~s}$, and $72{ }^{\circ} \mathrm{C}$ for $30 \mathrm{~s}$ in a GeneAmp 9600 (PerkinElmer, Irvine, CA, USA). As a loading control, the same amounts of cDNA template were amplified using GAPDH. Products were analyzed on $1.5 \%$ agarose gel and visualized by ethidium bromide staining.

Primer sequences were as follows: GAPDH $5^{\prime}$ untranslated region (5'-CAAGTTCAACGGCACA GTCA-3 $3^{\prime}$ ) and $3^{\prime}$ untranslated region $\left(5^{\prime}\right.$-CCACCACATACTCAGCACCAG-3'); OCT4 $5^{\prime}$ untranslated region (5'-AGGTGTTCAGCCAAACGACTATC-3') and $3^{\prime}$ untranslated region $\left(5^{\prime}\right.$-TCAGCTTCCTCCA CCCACTTC- $\left.3^{\prime}\right)$; SOX2 $5^{\prime}$ untranslated region $\left(5^{\prime}\right.$ TCAGATGCAGCCCATGCAC-3 ${ }^{\prime}$ ) and $3^{\prime}$ untranslated region (5'-GGTGCCCTGCTGAGAATAGGAC-3'); NANOG $5^{\prime}$ untranslated region $\left(5^{\prime}\right.$-CATC TGCTGACACCCTCGACA-3 $3^{\prime}$ ) and $3^{\prime}$ untranslated region (5'-GGGTCTGCGAGAACACAGTTCTAA-3').

Amplifications yielded products of $106 \mathrm{bp}$ (OCT4), $195 \mathrm{bp}$ (NANOG), $121 \mathrm{bp}$ (SOX2), and $128 \mathrm{bp}$ (GAPDH).

Real-time quantitative PCR (RT-qPCR)

The bovine embryonic stem cell-like colonies were processed using a RNAiso Reagent from TaKaRa (Shiga, Japan) using the manufacturer's recommendations. To completely remove genomic DNA contamination from the RNA extraction, we performed the incolumn DNAse I optional step using amplification grade DNAse I (Invitrogen ${ }^{\mathrm{TM}}$ ). A final volume of $15 \mu \mathrm{l}$ of RNAse free water was used in RNA elution. Only RNA samples with a 260/280 nm wavelength ratio above 2.00 were used for RT-qPCR assays. Approximately $650 \mathrm{ng}$ of RNA from each sample was used in subsequent reverse transcriptase reactions. Complementary DNA was synthesized using the PrimeScript ${ }^{\mathrm{TM}} \mathrm{RT}$ reagent Kit (Perfect Real Time, TaKaRa) according to the manufacturer's recommendations. Synthesis of the first strand was carried out at $37{ }^{\circ} \mathrm{C}$ for $15 \mathrm{~min}$ followed by a 15 s step at $85^{\circ} \mathrm{C}$ for inactivation of reverse transcriptase. Primers were designed using the Primer3 webtool with settings to generate primers with a melting temperature of $\sim 60{ }^{\circ} \mathrm{C}$. Due to the limitations of extension time in quantitative polymerase chain reactions (qPCR), primers were designed to amplify less than $200 \mathrm{bp}$ of sequence when possible.

All qPCR experiments were performed using the SYBR Premix $2 \times$ Ex Taq (TaKaRa). Reaction volumes were reduced to $20 \mu \mathrm{l}$. A 7300 Real Time PCR System (Applied Biosystems, Foster City, CA, 

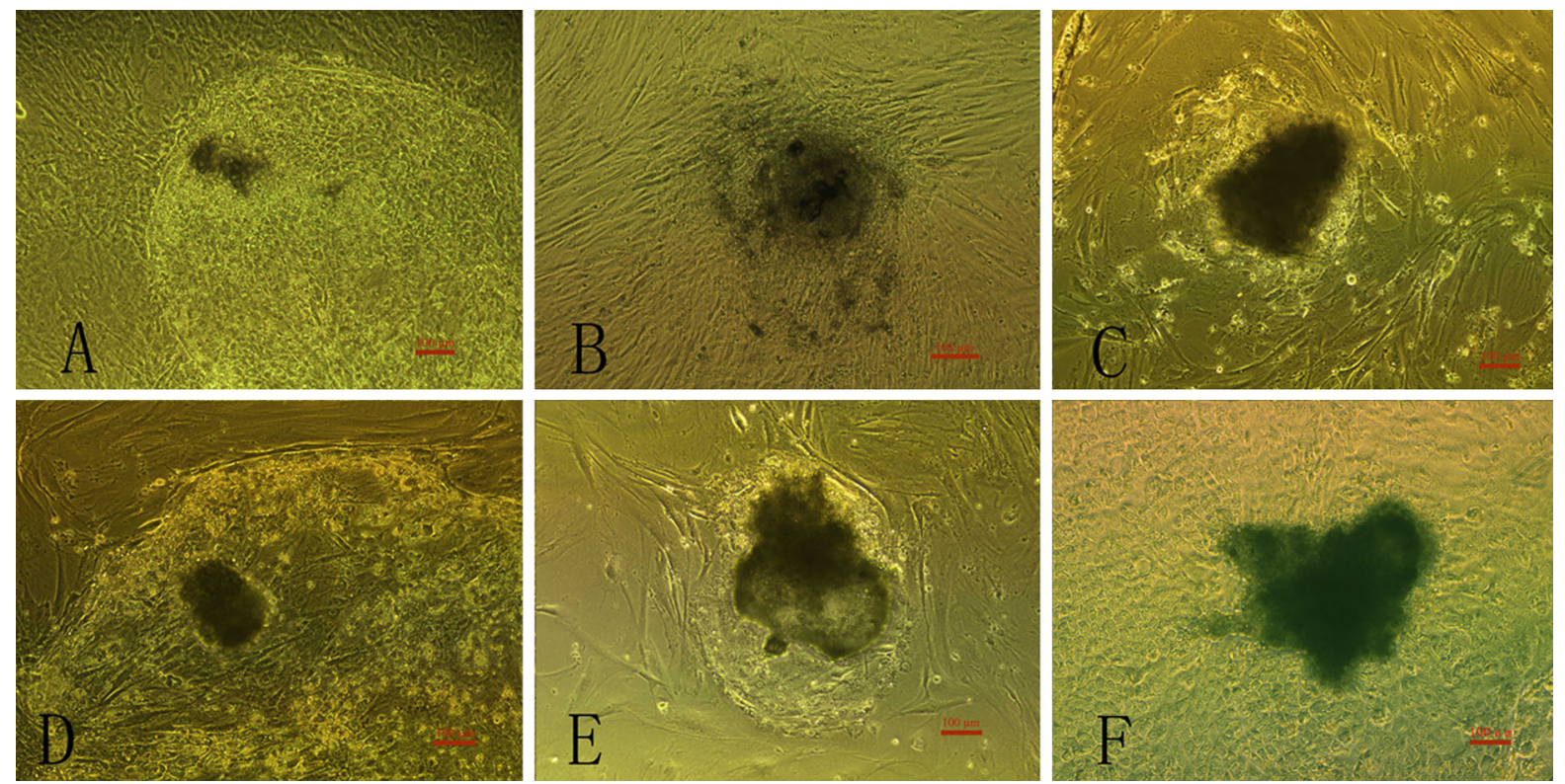

Fig. 1 The clonal morphology of bovine embryonic stem celllike cells in different feeder layers: mouse embryonic fibroblast feeder layers (a); bovine embryonic fibroblast feeder layers (b); mixed embryonic fibroblast feeder layer at a ratio of 1:1 (mouse embryonic fibroblast feeder layers: bovine embryonic fibroblast feeder layers) (c); mixed embryonic fibroblast feeder layers at a

USA) was used to quantify reactions. This was followed by one $95{ }^{\circ} \mathrm{C}$ denaturation for $30 \mathrm{~s}$. Temperature cycling consisted of the following: 35 cycles of $95{ }^{\circ} \mathrm{C}$ for $5 \mathrm{~s}$ then $60{ }^{\circ} \mathrm{C}$ for $30 \mathrm{~s}$. Melt curves (to determine if there were multiple PCR amplicons) were constructed by heating final amplified reactions from 60 to $95{ }^{\circ} \mathrm{C}$ for $15 \mathrm{~s}, 60{ }^{\circ} \mathrm{C} 30 \mathrm{~s}, 95^{\circ} \mathrm{C} 15 \mathrm{~s}$ in single degree stepwise fashion. Primer efficiencies were calculated from readings derived from a standard curve of known DNA concentrations. Relative expression levels of target genes were calculated using the standardization as previously described by Pfaffl (2001). The GAPDH was used as a reference gene to standardize relative expression in the samples.

\section{Statistical analysis}

All values are expressed as mean \pm SEM. Analysis of variance was used to determine the significance of differences among the groups. Values of $P<0.05$ were considered statistically significant. ratio of 2:1 (mouse embryonic fibroblast feeder layers: bovine embryonic fibroblast feeder layers) (d); mixed embryonic fibroblast feeder layers at a ratio of 1:2 (mouse embryonic fibroblast feeder layers: bovine embryonic fibroblast feeder layers) (e). STO cell feeder layers (f). Cells from the fifth passage are shown

\section{Results}

Growth of bovine embryonic stem cell-like cells on the different types of feeder layers

The bovine embryonic stem cell-like cells were cultured on murine or bovine embryonic fibroblast feeder layers at the fifth passage, which had a clear border and apparent limitation to surrounding cells. There was no apparent eminentia, with the clone centers differentiating easily. Moreover, the colonies were thin and flat, and had not obvious bordering (Fig. 1a, b), while on the mixed feeder layer, bovine embryonic stem cell-like cells obviously grew to assembled cell masses and had clear colony borders. Moreover, bovine embryonic stem cell-like colonies were thick and solid. When mouse and bovine embryonic feeder layers were mixed together according to a ratio of $1: 1$, bovine embryonic stem cell-like cells obviously compacted to cell masses and had 
Table 1 Average attachment rate of different ratios of mixed layers (mouse embryonic fibroblasts feeder layers: bovine embryonic fibroblasts feeder layers)

\begin{tabular}{llllll}
\hline & $1: 0$ & $1: 1$ & $1: 2$ & $2: 1$ & $0: 1$ \\
\hline Number of blastocyst & 84 & 87 & 95 & 82 & 85 \\
Number of attached blastocyst & 41 & 56 & 37 & 37 & 35 \\
The rate of attachment blastocyst $(\%)$ & $48.81 \pm 7.4^{\mathrm{b}}$ & $64.37 \pm 15.5^{\mathrm{a}}$ & $38.95 \pm 14.0^{\mathrm{c}}$ & $37.80 \pm 11.0^{\mathrm{c}}$ & $41.18 \pm 6.3^{\mathrm{b}}$ \\
\hline
\end{tabular}

Values with different superscripts are significantly different. Each experiment was repeated 3 times. Data are expressed as mean \pm SEM $(\mathrm{n}=3)$

${ }^{a} P<0.05$, when the mixed ratio was set $1: 1$, the rate of attachment blastocyst was obviously higher than for the other ratios $(P<0.05)$
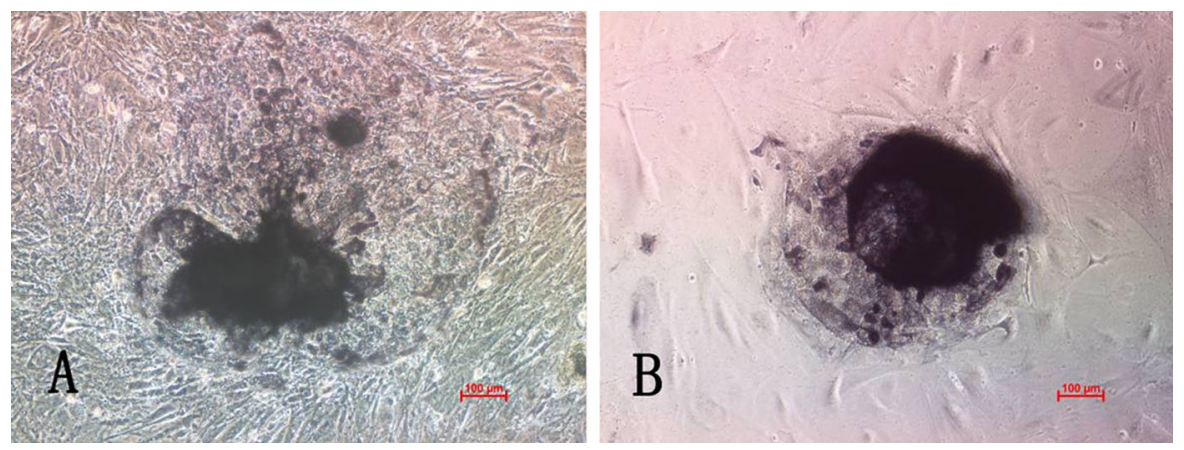

Fig. 2 Alkaline phosphatase staining of bovine embryonic stem cell-like cells: mixed embryonic fibroblast feeder layers of 1:1 (a); STO cell feeder layers (b). Both of which were positive for AP staining. Cells from the tenth passage are shown

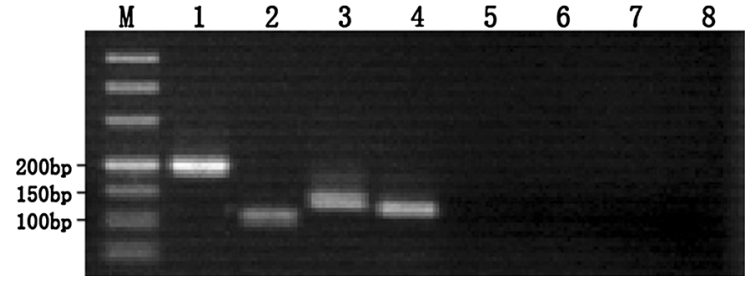

Fig. 3 The RT-PCR analysis of bovine embryonic stem cell-like cells. OCT4, SOX2 and NANOG gene mRNA levels were observed in bovine embryonic stem cell-like cells cultured on mixed embryonic fibroblast feeder layers at 1:1 (similar results were obtained for bovine embryonic stem cell-like cells grown on STO cell feeder layers). Cells from the eighth passage are shown. $M$ (50 bp) maker; 1 NANOG (195 bp); 2 OCT4 (106 bp); 3 SOX2 (121 bp); 4 GAPDH (128 bp); 5-8 negative control

obvious boundaries with the feeder layer (Fig. 1c-e). The rate of attachment of blastocysts in the 1:1 ratio was significant higher $(P<0.05)$ than at the other ratios (Table 1). Similarly, the fifth passage of bovine embryonic stem cell-like cells on STO cell feeder layers were thick and closely connected to each other, with clear colony borders and obvious boundaries between the trophoblasts (Fig. 1f).
Differentiation of bovine embryonic stem cell-like cells in different feeder layers

Bovine embryonic stem cell-like colonies were classified as stem or differentiated colonies according to detection of undifferentiated state. On mixed embryonic fibroblast feeder layers and STO cell feeder layers, the tenth generation of bovine embryonic stem cell-like cells was respectively positive for ALP staining (Fig. 2a, b). The relative pluripotency-related levels of mRNA transcripts (expression levels) were monitored in bovine embryonic stem cell-like cells by using RT-PCR. The results showed that OCT4, SOX2 and NANOG were expressed in bovine embryonic stem cell-like cells on mixed embryonic fibroblast feeder layers at 1:1 and STO cell feeder layers. Cells from the eighth passage are shown (Fig. 3). Furthermore, bovine embryonic stem cell-like colonies on mixed embryonic fibroblast feeder layers at the tenth passage strongly stained positive for OCT4 (Fig. 4a) and SSEA-1 (Fig. 4b). Similarly, OCT4 (Fig. 4c) and SSEA4 (Fig. 4d) were also strongly stained in undifferentiated bovine embryonic stem cell-like cells on STO cell feeder 


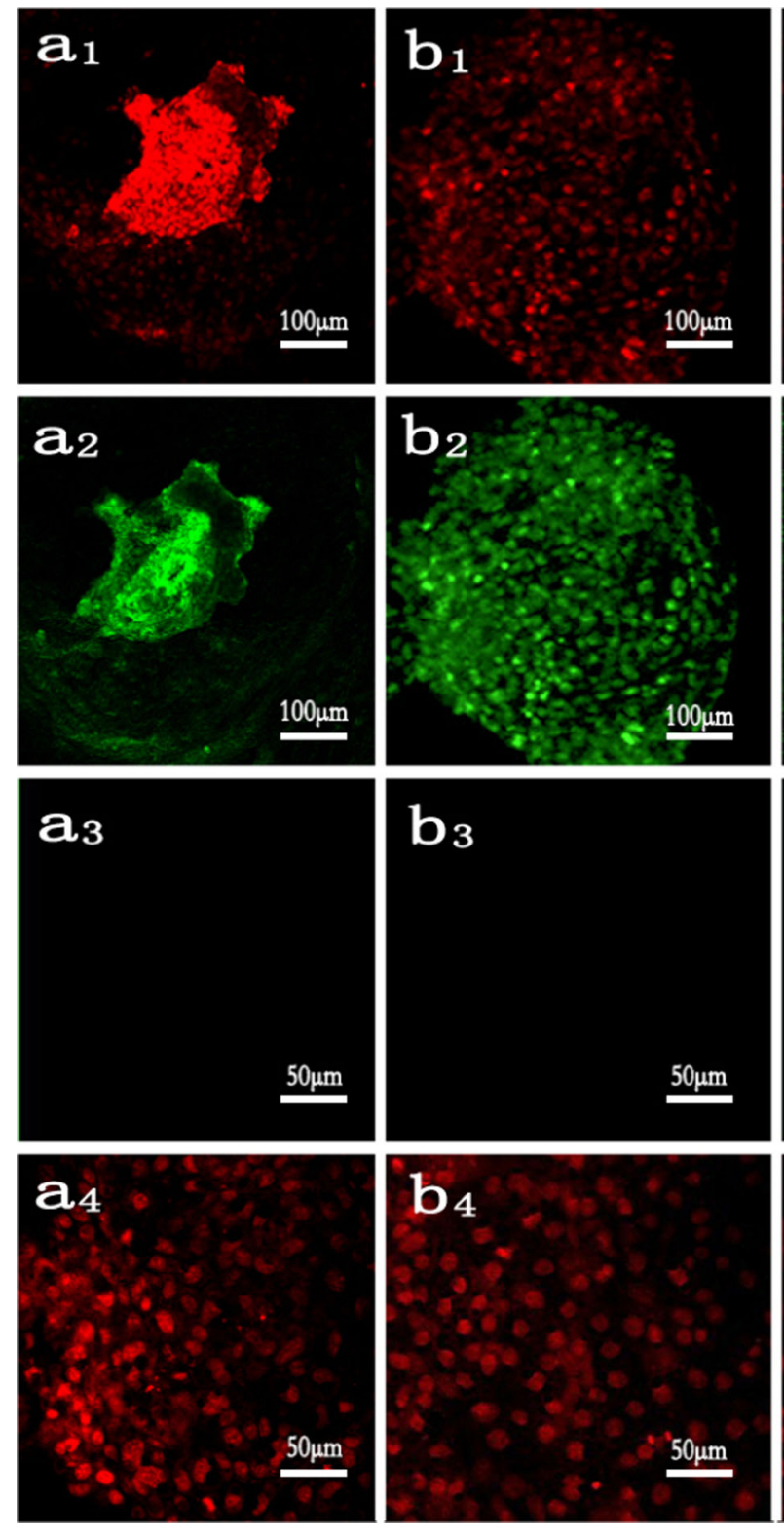

Fig. 4 Representative immuonofluorescence images showing expression of OCT4, SSEA-1, and SSEA-4 in the bovine embryonic stem cell-like colony. Bovine embryonic stem celllike colonies cultured on mixed embryonic fibroblast feeder layers were stained positively for OCT4 (a2) and SSEA-1 (b2); Bovine embryonic stem cell-like cells cultured on STO cell

layers at the tenth passage. When cultured for 7-10 days in medium without LIF, the eighth generation of bovine embryonic stem cell-like cells on mixed embryonic fibroblast feeder layers and STO cell feeder layers, respectively, spontaneously differentiated into EBs (Fig. 5a, b).
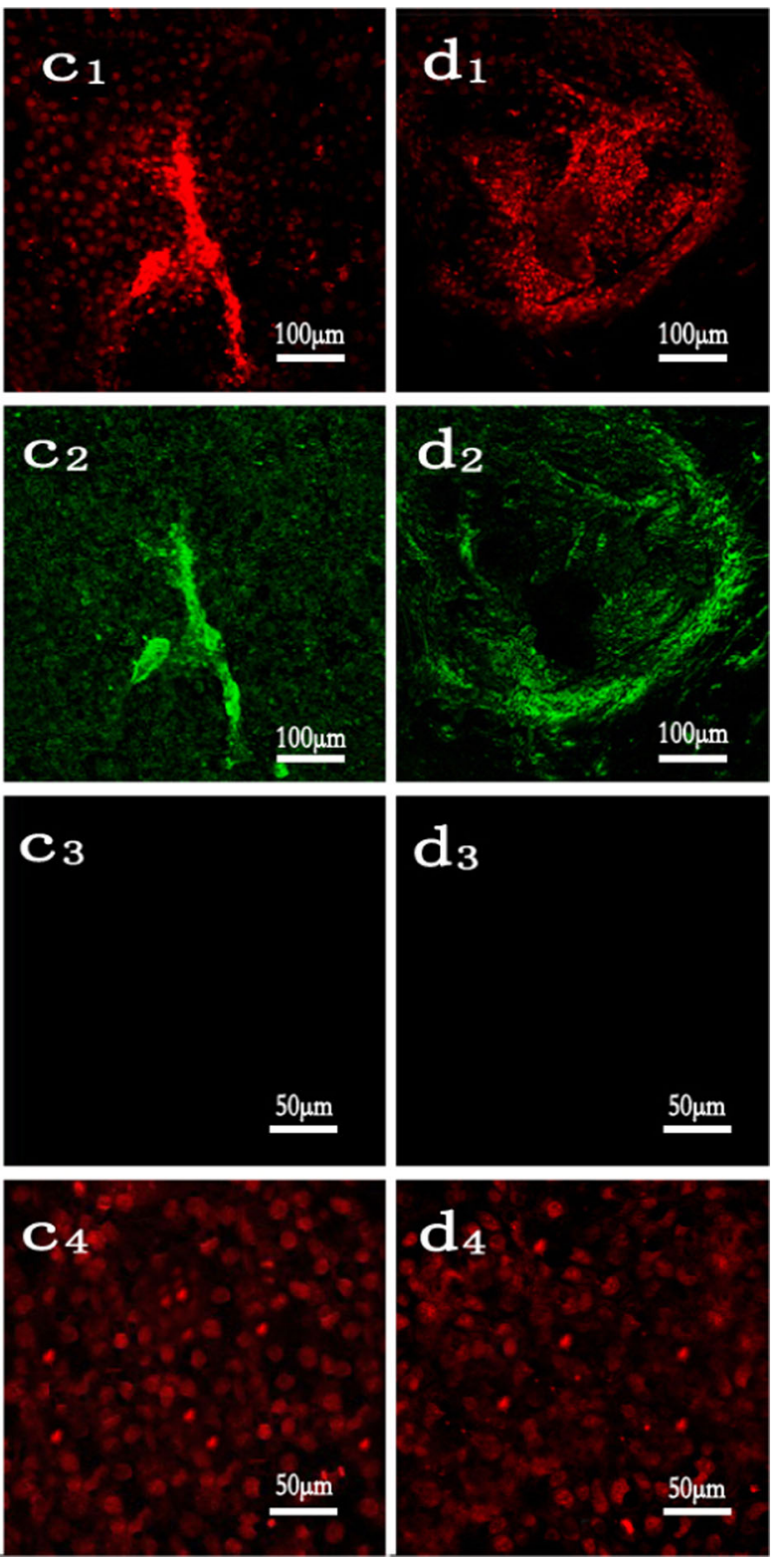

feeder layers were also stained positively for OCT4 (c2) and SSEA-4 (d2); negative controls for OCT4 (a3, c3), SSEA-4 (d3) and SSEA-1 (b3). All cells were stained with DAPI to highlight the nucleus (a1-d1), and negative controls were stained with DAPI (a4-d4). Cells from the tenth passage are shown

Pluripotency-related gene expression in mouse embryonic fibroblast feeder layers

Bovine embryonic stem cell-like colonies on mouse embryonic fibroblast feeder layers at passages 1-5 were individually collected and mRNA transcript 


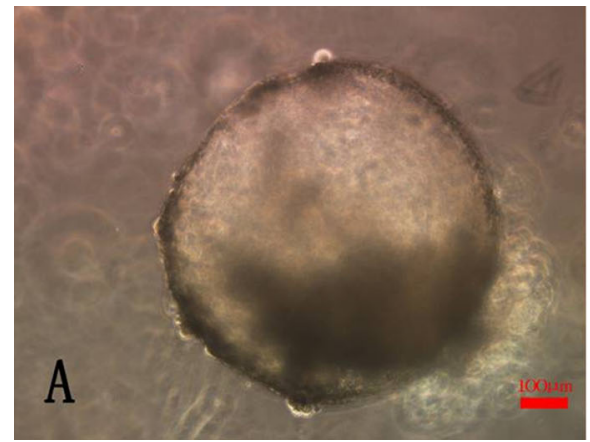

Fig. 5 EBs differentiated in medium without leukemia inhibitory factor and feeder layer. Bovine embryonic stem cell-like cells had differentiated spontaneously into EBs on mixed

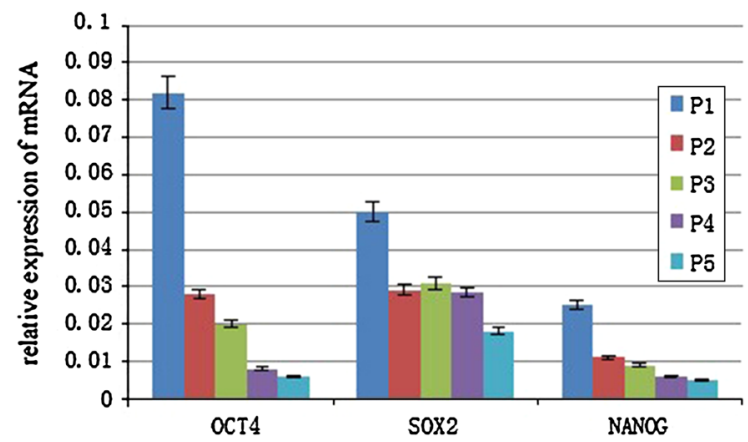

Fig. 6 Relative expression of the major pluripotency-related transcription factors in bovine embryonic stem cell-like cells cultured on murine embryonic fibroblast feeder layers. Expression of OCT4, SOX2 and NANOG were significantly lower in the fifth passage than in the first passage. Cells from the first passage to fifth passage are shown

levels were determined by quantitative RT-PCR. The data showed that the OCT4, SPX2, and NANOG levels were found to be significantly reduced in the fifth passage of bovine embryonic stem cell-like cells compared to those in the first passage (Fig. 6).

Comparison of pluripotency-related gene expression in three feeder layers

The tenth generation of bovine embryonic stem celllike cells on mixed embryonic fibroblast feeder layers, including mouse fibroblast cell line feeder layers and mouse embryonic fibroblast feeder layers, mouse embryonic feeder layers and STO cell feeder layers were individually collected and mRNA transcript levels were determined by quantitative RT-PCR. The results demonstrated that OCT4, SOX2, and NANOG

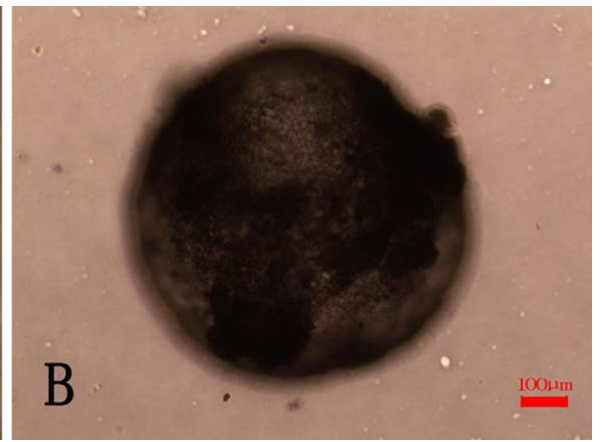

embryonic fibroblast feeder layers (a) and STO cell feeder layers (b). Cells from the eighth passage are shown

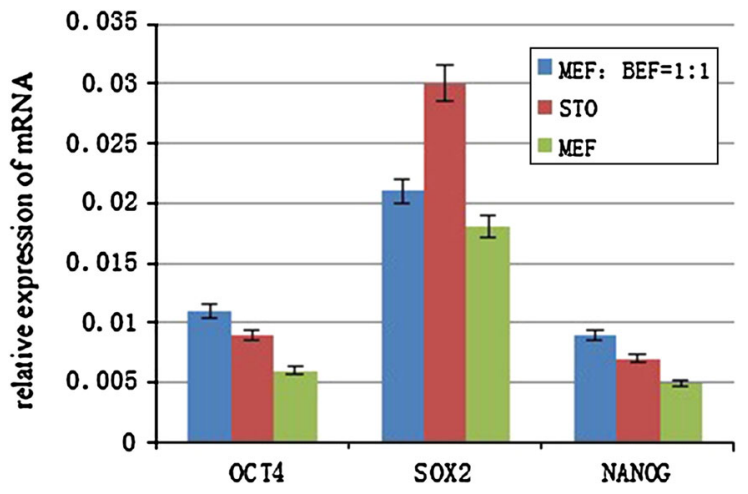

Fig. 7 Comparison of OCT4, SOX2, and NANOG expression in bovine embryonic stem cell-like cells cultured on murine embryonic fibroblast feeder layers, STO cell feeder layers and mixed embryonic fibroblast feeder layers. OCT4, SOX2, and NANOG expression in bovine embryonic stem cell-like cells was significantly higher when cultured on STO cell feeder layers and mixed embryonic fibroblast feeder layers than on murine embryonic fibroblast feeder layers. Cells from the tenth passage are shown

were expressed at significantly higher levels on mixed embryonic fibroblast feeder layers and STO cell feeder layers than on mouse embryonic feeder layers (Fig. 7).

\section{Discussion}

The derivation and maintenance of embryonic stem cell lines from bovine blastocysts is perhaps the most difficult and challenging among all mammals (Gong et al. 2010). Therefore, improvements are needed in order to supply defined feeder cells to bovine 
embryonic stem cells culture. In the present study, we demonstrated that OCT4, SOX2, and NANOG levels were found to be significantly lower in the fifth passage of bovine embryonic stem cell-like cells than in the first passage, when bovine embryonic stem cell-line cells were cultured on murine embryonic fibroblast feeder layers at 1-5 passages. However, recent findings identifying high levels of OCT4, SOX2, and NANOG are associated with pluripotency and self-renewal, while low levels are associated with a tendency to differentiation (Avilion et al. 2003; Pesce and Schöler 2001; Miyanari and Torres-Padilla 2012). This may be the reason that bovine embryonic stem cell-like cells cannot continue to grow and to be passaged. Obviously, it is important to look for a new feeder layer system which could sustain the pluripotency and undifferentiated state of bovine embryonic stem cell-like cells. We have shown that the morphology of bovine embryonic stem cell-like cells on mixed embryonic fibroblast feeder layers was obvious better than when culturing on single embryonic fibroblast feeder layers. The reasons for this may be that mouse embryonic fibroblast feeder layers have a shorter growth time and stronger growth, and secrete factors such as LIF that promote embryonic stem cell growth when used as feeder layers (Jin et al. 2012). Mouse embryonic fibroblast feeder layers also could widely provide space for growth. Meanwhile, bovine embryonic fibroblast feeder layers as homologous feeder layers easily fused with trophoblast so as to effectively prevent embryonic stem cells transformation to trophoblast stem cells (Talbot and Powell 1995). Owing to the molecule affinity on both embryonic stem cells and fibroblasts surface, embryonic stem cells can easily attach onto feeder cells. Therefore, the mouse embryonic fibroblast feeder layers in common with bovine embryonic fibroblast feeder layers could mutually promote the adherence of bovine embryos and inhibit the differentiation of bovine embryonic stem cell-like cells. Furthermore, mouse embryonic fibroblast feeder layers and bovine embryonic fibroblast feeder layers at a ratio of 1:1 was superior not only with respect to morphology of the cells, but also to the higher adherence rate of bovine embryos. In addition, we also found that the two embryonic fibroblast at this ratio could be cultivated to the fifteenth generation at least, whereas at the ratio of $1: 2$ or $2: 1$, they could be only cultivated to the sixth and eighth generations, respectively, and the cells had differentiated. Thus, the mixed embryonic fibroblast feeder layers at ratio of 1:1 might better support in vitro subculture of bovine embryonic stem cell-like cells to acquire excellent colony form compared to mouse or bovine embryonic fibroblast feeder layers. Apparently, the mixed embryonic fibroblast feeder layers could completely replace the routine mouse or bovine embryonic fibroblast feeder layers.

In this study, the bovine embryonic stem cell-like cells on STO cell feeder layers grew in assembled cell masses and had clear colony borders. The cells were dense and circular, which had an obvious boundary with trophoblast layers. Two or three days after subculturing, the primary colony formation rate was around $47 \%$, which is within the range of reported colony formation (13-67 \%) (Stice et al. 1996; Strelchenko 1996; Park et al. 2003; Gong et al. 2010). Recently, it has been suggested that STO cells as feeder layers could promote the adherence of the embryonic stem cells and could also secrete a variety of factors which can maintain the undifferentiation state of embryonic stem cells, such as leukemia inhibitory factor or basic fibroblast growth factor (Talbot and Powell 1995; Park et al. 2004). This may be the reason why bovine embryonic stem cell-like cells have a better morphology and higher primary colony formation rate on STO cell feeder layers. When STO cells were prepared as feeder layers, we also found that the morphology of STO cells reached the optimal growth stage at the fifth passage. Less than ten passages of STO cells are considered as optimal for their use as feeder layers. Originally, with long-term culture and passage, trypsin and the toxic effects of mitomycin had a side effect on STO cells even when trypsin and mitomycin were washed out. The changes that included proliferation, morphology and viability of STO cells affected the quality of the STO cells as a feeder layer for embryonic stem cell growth. Compared with mouse embryonic fibroblast cells, STO cells could be cultured long-term in vitro. STO cell is widely and conveniently used for culturing hybridoma cells, pluripotent teratocarcinoma cells and a variety of animal pluripotent stem cells (Chen et al. 1999; Martin et al. 1977; Lim and Bodnar 2002; Martin and Evans 1975). Moreover, bovine embryonic stem cell-like cells were identified that had the characteristics of stem cells. Therefore, STO cell feeder layers have the potential to support the establishment and maintenance of bovine embryonic stem cell-like cells. 
We also demonstrated that OCT4, SOX2, and NANOG were expressed at significantly higher levels in bovine embryonic stem cell-like cells cultured on mixed embryonic fibroblast feeder layers and STO cell feeder layers than on mouse embryonic fibroblast feeder layers. This result implies that the mixed embryonic fibroblast feeder layers and STO cell feeder layers are superior in regulation of self-renewal and differentiation of bovine embryonic stem cell-like cells than mouse embryonic fibroblast feeder layers. Therefore, the STO cell feeder layers and mixed embryonic fibroblast feeder layers are more suitable than murine embryonic fibroblast feeder layers for the culture of bovine embryonic stem cell-like cells.

In conclusion, our study strongly suggests that mixed embryonic fibroblast feeder layers and STO cell feeder layers can be used as valuable candidate feeder layers to support the cultivation and isolation for bovine embryonic stem cell-like cells.

Acknowledgments This work was supported by Grants from the National High Technology Research and Development Program of China ("863" Program) (2008AA101005). We gratefully thank Dr. Dongjun Liu (Inner Mongolia University) for providing the directions.

Open Access This article is distributed under the terms of the Creative Commons Attribution License which permits any use, distribution, and reproduction in any medium, provided the original author(s) and the source are credited.

\section{References}

Anand T, Kumar D, Singh MK, Shah RA, Chauhan MS, Manik RS, Singla SK, Palta P (2011) Buffalo (Bubalus bubalis) embryonic stem cell-like cells and preimplantation embryos exhibit comparable expression of pluripotencyrelated antigens. Reprod Domest Anim 46:50-58

Avilion AA, Nicolis SK, Pevny LH, Perez L, Vivian N, LovellBadge R (2003) Multipotent cell lineages in early mouse development depend on SOX2 function. Genes Dev 17:126-140

Bettiol E, Sartiani L, Chicha L, Krause KH, Cerbai E, Jaconi ME (2007) Fetal bovine serum enables cardiac differentiation of human embryonic stem cells. Differentiation 5:669-681

Bryja V, Bonilla B, Arenas E (2006) Derivation of mouse embryonic stem cells. Nat Protoc 1:2082-2087

Chen LR, Shiue YL, Bertolini L, Medrano JF, BonDurant RH, Anderson GB (1999) Establishment of pluripotent cell lines from procine preimplantation embryos. Theriogenology 52:195-212

Christoforou N, Oskouei BN, Esteso P, Hill CM, Zimmet JM, Bian W, Bursac N, Leong KW, Hare JM, Gearhart JD
(2010) Implantation of mouse embryonic stem cell-derived cardiac progenitor cells preserves function of infarcted murine hearts. PLoS One 5:e11536

Cibelli JB, Stice SL, Golueke PJ, Kane JJ, Jerry J, Blackwell C, Ponce de León FA, Robl JM (1998) Transgenic bovine chimeric offspring produced from somatic cell-derived stem-like cells. Nat Biotechnol 16:642-646

Evans MJ, Kaufman MH (1981) Establishment in culture of pluripotential cells from mouse embryos. Nature 292:154-156

Gong GC, Roach ML, Jiang L, Yang X, Tian XC (2010) Culture conditions and enzymatic passaging of bovine ESC-like cells. Cell Reprogram 12:151-160

Graves KH, Moreadith RW (1993) Derivation and characterization of putative pluripotential embryonic stem cells from preimplantation rabbit embryos. Mol Reprod Dev 36:424-433

Huang B, Li T, Wang XL, Xie TS, Lu YQ, da Silva FM, Shi DS (2010) Generation and characterization of embryonic stem-like cell lines derived from in vitro fertilization Buffalo (Bubalus bubalis) embryos. Reprod Domest Anim 45:122-128

Iwasaki S, Campbell KHS, Galli C, Akiyama K, Iwasaki S (2000) Production of live calves derived from embryonic stem-like cells aggregated with tetraploid embryos. Biol Reprod 62:470-475

Jin MZ, Wu AG, Dorzhin S, Yue QH, Ma YZ, Liu DJ (2012) Culture conditions for bovine embryonic stem cell-like cells isolated from blastocysts after external fertilization. Cytotechnology 64:379-389

Li M, Li YH, Hou Y, Sun XF, Sun Q, Wang WH (2004) Isolation and culture of pluripotent cells from in vitro produced porcine embryos. Cambridge Univ Press 12:43-48

Lim JW, Bodnar A (2002) Proteome analysis of conditioned medium from mouse embryonic fibroblast feeder layers which support the growth of human embryonic stem cells. Proteomics 2:1187-1203

Martin GR, Evans MJ (1975) Differentiation of clonal lines of teratocarcinoma cells: formation of embryoid bodies in vitro. Proc Natl Acad Sci USA 72:1441-1445

Martin GR, Wiley LM, Damjanov I (1977) The development of cystic embryoid bodies in vitro from clonal teratocarcinoma stem cells. Dev Biol 61:230-244

Mitalipova M, Beyhan Z, First NL (2001) Pluripotency of bovine embryonic cell line derived from precompacting embryos. Cloning 3:59-67

Miyanari Y, Torres-Padilla ME (2012) Control of ground-state pluripotency by allelic regulation of Nanog. Nature 483:470-473

Muñoz M, Rodríguez A, De Frutos C, Caamaño JN, Díez C, Facal N, Gómez E (2008) Conventional pluripotency markers are unspecific for bovine embryonic-derived celllines. Theriogenology 69:1159-1164

Park JH, Kim SJ, Oh EJ, Moon SY, Roh SI, Kim CG, Yoon HS (2003) Establishment and maintenance of human embryonic stem cells on STO, a permanently growing cell line. Biol Reprod 69:2007-2014

Park SP, Lee YJ, Lee KS, Shin HA, Cho HY, Chung KS, Kim EY, Lim JH (2004) Establishment of human embryonic stem cell lines from frozen-thawed blastocysts using STO cell feeder layers. Hum Reprod 19:676-684 
Pesce M, Schöler HR (2001) Oct-4: gate keeper in beginning of mammalian development. Stem Cells 19:271-278

Pfaffl MW (2001) A new mathematical model for relative quantification in real-time RT-PCR. Nucleic Acids Res 29:2003-2007

Piedrahita JA, Anderson GB, Bondurant RH (1990) Influence of feeder layer type on the efficiency of isolation of porcine embryo-derived cell lines. Theriogenology 34:865-877

Reubinoff BE, Pera MF, Fong CY, Trounson A, Bonso A (2000) Embryonic stem cell lines from human blastocysts: somatic differentiation in vitro. Nat Biotechnol 18:399-404

Roach M, Wang L, Yang XZ, Tian XC (2006) Bovine embryonic stem cells. Method Enzymol 418:21-37

Saito S, Sawai K, Ugai H, Moriyasu S, Minamihashi A, Yamamoto Y, Hirayama H, Kageyama S, Pan J, Murata T, Kobayashi Y, Yokoyama KK, Obata Y (2003) Generation of cloned calves and transgenic chimeric embryos from bovine embryonic stem-like cells. Biochem Biophys Res Commun 309:104-113

Seizo H, Yoshie W, Sadahiro A, Yutaka T (1998) Establishment of embryonic stem (ES) cell-like cell lines derived from bovine blastocysts obtained by in vitro culture of oocytes matured and fertilized in vitro. J Reprod Dev 44:297-303

Smith AG, Hooper ML (1987) Buffalo rat liver cells produce a diffusible activity which inhibits the differentiation of murine embryonal carcinoma and embryonic stem cells. Dev Biol 121:1-9

Stice SL, Strelchenko NS, Keefer CL, Matthews L (1996) Pluripotent bovine embryonic cell lines direct embryonic development following nuclear transfer. Biol Reprod 54:100-110
Strelchenko N (1996) Bovine pluripotent stem cells. Theriogenology 45:131-140

Sun Y, Li H, Yang H, Rao MS, Zhan M (2006) Mechanisms controlling embryonic stem cell self-renewal and differentiation. Crit Rev Eukaryot Gene Expr 16:211-231

Takahashi K, Yamanaka S (2006) Induction of pluripotent stem cells from mouse embryonic and adult fibroblast cultures by defined factors. Cell 126:663-676

Talbot NC, Powell AM, Rexroad CE (1995) In-vitro pluripotency of epiblasts derived from bovine blastocysts. Mol Reprod Dev 42:35-52

Tervit HR, Wittingham DG, Rowson LE (1972) Successful culture in vitro of sheep and cattle ova. J Reprod Fertil 30:493-497

Thomson JA, Itskovitz-Eldor J, Shapiro SS, Waknitz MA, Swiergiel JJ, Marshall VS, Jones JM (1998) Embryonic stem cell lines derived from human blastocysts. Science 282:1145-1147

Wang L, Duan EK, Sung LY, Jeong BS, Yang X, Tian XC (2005) Generation and characterization of pluripotent stem cells from cloned bovine embryos. Biol Reprod 73:149-155

Wells DN, Misica PM, Day TA, Tervit HR (1997) Production of cloned lambs from an established embryonic cell line: a comparison between in vivo- and in vitro-matured cytoplasts. Biol Reprod 57:385-393

Zeevi-Levin N, Itskovitz-Eldor J, Binah O (2010) Functional properties of human embryonic stem cell-derived cardiomyocytes. Crit Rev Eukaryot Gene Expr 20:51-59 